\title{
What Do Managers Mean When They Say 'Firms Like Theirs' Pay Bribes?
}

\author{
George R. G. Clarke \\ Correspondence: George Clarke, Division of International Banking and Finance Studies, A.R. Sanchez, Jr. \\ School of Business, Texas A\&M International University, 5201 University Boulevard, Laredo, Texas 78041, \\ USA. Tel: 1-956-326-255. E-mail: George.Clarke@tamiu.edu
}

Received: August 8, 2012

Accepted: August 28, 2012

Online Published: September 14, 2012

doi:10.5539/ijef.v4n10p161

\author{
URL: http://dx.doi.org/10.5539/ijef.v4n10p161
}

\begin{abstract}
It is difficult to get firm managers to answer questions on corruption honestly. Because of this, most surveys ask about corruption indirectly - asking whether corruption is a problem or whether 'firms like this one' pay bribes. Most studies interpret managers' responses to indirect questions as if they were answering about their own behavior. This might not be the case, however. This paper uses data from a survey of construction contractors in Afghanistan to look at how managers respond to indirect questions. We show that firms that are averse to paying bribes to win government contracts, and so do not bid for them, are more likely to say that firms like theirs pay bribes at other times. If managers answer the general indirect questions on corruption thinking about their own actions, we would expect that firms that are averse to paying bribes to win contracts would also be averse to paying bribes at other times. One explanation for the counterintuitive result is that firms answer the indirect questions as asked - about what they believe other firms are doing. This has important implications for studies that use indirect questions to assess what types of firms pay bribes.
\end{abstract}

Keywords: corruption, indirect questions, firm surveys, lying

\section{Introduction}

People often lie when asked sensitive questions during surveys. Men consistently report that they have had more partners of the opposite sex than women do. This is difficult to explain even with explanations such as prostitutes skewing the female average (Wiederman, 1997). Meters that record what music people listen to show men spend more time listening to soft rock and less time listening to classical music than they report during surveys (Clausen, Kraay, \& Murrell, 2010). Over half of people with high-interest rate consumer loans in South Africa denied having them during a survey (Karlan \& Zinman, 2008). Other studies have found that people often do not admit that they use alcohol and illegal drugs, use birth control, have had an abortion or have gastrointestinal problems during surveys (Tourangeau and Smith, 1996).

Lying is also a problem for firm surveys that ask about sensitive topics such as corruption (Azfar \& Murrell, 2009; Clausen et al., 2010). To decrease underreporting most surveys ask questions indirectly. For example, rather than asking about the firm's own experience with corruption, most surveys ask whether corruption is a serious problem or how much the manager thinks other firms pay in bribes. It is hoped that indirect phrasing will decrease underreporting by allowing managers to admit to paying bribes without incriminating themselves (Note 1).

Even if indirect questions lessen underreporting, it is difficult to interpret the answers. That is, managers might answer with their own actions in mind or might answer based on what they think others do. Managers who believe their competitors win government contracts unfairly, avoid paying taxes, or get licenses more quickly by paying bribes might say that corruption is a problem or that firms like theirs pay bribes even if they do not themselves. If managers answer indirect questions as they are asked, it will be difficult to relate bribes with firm and manager characteristics.

Some evidence suggests that firms do not always answer indirect questions with their own actions in mind. Managers of firms that do not bid for government contracts are more likely to say that corruption is a problem when bidding for government contracts than managers of firms that do bid (Clarke, 2011b). This suggests that managers are not implicitly admitting to paying bribes when they say corruption in government contracting is a 
problem. One explanation for why firms that do not bid might say corruption is a problem is that firms that are averse to paying bribes might refuse to bid for government contracts. By stopping them from getting contracts, corruption therefore affects them even though they do not pay bribes.

This paper shows the same firms were also more likely to say that corruption is a serious problem and that firms like theirs paid bribes in situations unrelated to bidding. It seems unlikely that firms that are averse to paying bribes when bidding for contracts will pay bribes more often at other times. A more likely explanation is that firms answer indirect questions thinking about what other firms do. This implies researchers should interpret indirect questions about corruption with care - managers might answer the questions thinking about other firms not their own firm.

\section{Asking Firms about Corruption}

Most firm-level surveys ask questions about corruption indirectly. Rather than asking whether the firm has paid bribes, the interviewer ask managers whether corruption is a problem, whether other firms like the managers' firm pay bribes, or whether bribes are needed or sought (rather than paid). This allows managers to answer the questions without admitting to paying bribes. For example, the two main questions on corruption in the World Bank's Enterprise Surveys are:

(J7) “We've heard that establishments are sometimes required to make gifts or informal payments to public officials to get things done with regard to customs, taxes, licenses, regulations, services etc. On average, what percentage of total annual sales, or estimated annual value, do establishments like this one pay in informal payments/gifts to public officials for this purpose?"

And

(J30f) "As I list some of many factors that can affect the current operations of a business, please look at this card and tell me if you think that [Corruption] is No Obstacle, a Minor Obstacle, a Major Obstacle, or a Very Severe Obstacle to the current operations of this establishment."

Other cross-country and one-off surveys have used similar indirect questions (Note 2). This paper focuses on questions similar to question J7 and J30f above - on whether 'firms like this one' sometimes pay bribes and whether corruption is a serious obstacle.

The problem with indirect questions is that it is not clear what firm managers mean when they answer. This is clear for questions like J30f that ask whether corruption is a problem. A manager that pays a bribe to avoid paying taxes or complying with regulations might see corruption as useful rather than harmful. Similarly, managers who refuse to pay bribes might see corruption as a problem if they lose contracts or cannot get permits or licenses because they refuse. Indirect questions that ask about 'firms like this one' have similar problems. Firm managers that don't pay bribes but believe that their competitors do might say that 'firms like theirs' pay bribes even if they do not.

Although the questions are ambiguous, most studies using indirect questions assume that firms answer these questions thinking about their own behavior (Note 3). If a firm managers says that 'firms like theirs' pay bribes equal to 2 percent of sales, most studies assume the firm pays that amount. In a recent paper on cross-country determinants of corruption, Treisman (2007, p. 214) notes '[w]ording is often chosen to reduce respondents' fear of self-incrimination - e.g., questions concern 'firms like yours' - but it is hoped and assumed that respondents reply based on their own experiences." Similarly, if a manager says corruption is a problem, studies often assume that is because that firm pays bribes more frequently. Safavian, Graham and Gonzalez-Vega (2001, p. 1220), for example, note:

"All questions in the survey asked the respondent to rate the level of corruption, on a one to four scale, in terms of problems of irregular payments or unprofessional behavior of local government officials. For the empirical work, we make the assumption that an individual firm's rating is correlated with its individual experience in bribery payments."

Anecdotal evidence on whether managers answer this way is mixed. Johnson, McMillan, and Woodruff (2002, p. 1337-1338) report one respondent told an interviewer that he understood that the question was really asking about his own firm. During field interviews in Zambia, however, when asked whether bribes were sometimes needed (i.e., question J7) several managers explicitly noted that although they do not pay bribes-often giving reasons why they do not-they know other firms do (Note 4). It is unclear, whether the managers did this maintain the illusion that they do not pay bribes or because they were truthfully answering questions based on what they believe other firms do. 
In summary, indirect questions are difficult to interpret. That is, firms that say corruption is a problem or that firms like theirs pay bribes might not answer questions with their own actions in mind. If this is the case, firm-level analysis of firms' answers will tell you what types of firms and managers believe others pay bribes not what types of firms or managers pay bribes. The goal of this paper is to provide additional evidence on whether firms answer indirect questions with their own experiences in mind.

\section{Data}

This paper uses data from survey of 144 construction firms in Kabul (Afghanistan) that was conducted between May and June 2009. The survey was a general business environment survey-only six of the 114 questions concerned corruption. The questionnaire was based on the World Bank's Enterprise Survey. Firms were randomly selected from the database of 1165 construction firms held by the Peace Dividend Trust (PDT). PDT uses the database to help construction firms access information and bid for contracts. Because construction contractors need to keep their information current to receive information, it is probably the most comprehensive database of construction contractors available in the country.

\section{Corruption in Public Contracting}

Afghanistan has serious problems with corruption, including in government contracting. As well as asking general questions about corruption (e.g., J30f and J6), the survey included questions about corruption in government contracting. Managers were asked whether corruption was a serious problem when bidding for government contracts. About 69 percent of managers said that it was. Corruption was seen as the most serious problem related to bidding for government contracts (see Table 1).

Table 1. Barriers to bidding on government contracts

\begin{tabular}{lc}
\hline & All Firms \\
\hline Corruption & $69 \%$ \\
Unfair selection methods & $32 \%$ \\
Provisions for price escalation & $30 \%$ \\
High bid bonds & $23 \%$ \\
Procurement procedures & $20 \%$ \\
Size of contracts & $18 \%$ \\
Dispute resolution procedures & $15 \%$ \\
Insurance & $10 \%$ \\
Technical/experience requirements & $10 \%$ \\
\hline
\end{tabular}

Source: Author's calculations based upon data from survey.

Construction firms that are averse to paying bribes have another option in Afghanistan. International donors and foreign militaries finance much of the construction in the country (Note 5). Since corruption is a less serious problem for these contracts, firms that are averse to paying bribes can focus on bids with these organizations (Note 6). Many firms do this, bidding for international, but not government, contracts (see

Table 2).

Table 2. Number of firms bidding on government and non-government contracts

\begin{tabular}{lcccc}
\hline \multirow{2}{*}{ No of Firms } & & \multicolumn{3}{c}{ Bids on International Contracts } \\
& & No & Yes & 44 \\
Total \\
\hline \multirow{2}{*}{ Bids on Government Contracts } & No & 17 & 74 & $\mathbf{6 1}$ \\
& Yes & 9 & $\mathbf{8 3}$ & $\mathbf{1 4 4}$ \\
\hline
\end{tabular}

Source: Authors' calculations based upon data from survey. Note: Counts are unweighted

Managers who do not bid for government contracts are more likely to say corruption is a problem than managers that do bid for government contracts (Clarke, 2011b). About 77 percent of managers that had not bid said that corruption was a serious problem compared with 63 percent of managers that had bid (Note 7). This suggests that firms that say corruption is a problem are not implying that they pay bribes. That is, firms that do not bid do not pay bribes to win government contracts. 
So why are firms that only bid for contracts with international organizations more concerned about corruption than firms that bid for government contracts? It might be because managers who are averse to paying bribes avoid bidding for government contracts because they believe that they have to pay bribes to compete (Clarke, 2011b). These managers, who feel that they lose potential contracts because of corruption, might therefore see corruption as an especially serious problem.

For this explanation to explain the pattern of responses, some people would have to be more averse to paying bribes than others. There are several reasons why this might be the case. Some people might be more apprehensive about breaking the law, more worried about being caught, or more concerned about how corruption affects society. Another possibility is that non-bidders are less well connected. They therefore might find it harder to know who to bribe and how much to pay (Note 8). Moreover, in the absence of a legally enforceable agreement, they might worry that they will not win the contract after paying the bribe.

In summary, the results suggest that firms that say corruption is a problem during the bidding process are not implicitly admitting to paying bribes. Firms that do not bid do not pay bribes. They do, however, report being more concerned about corruption during bidding than firms that do bid. This makes it difficult to interpret responses to this indirect question as if firms are talking about their own behavior. In the next section, we explore this issue further looking at general questions about corruption.

\section{Econometric Estimation}

The question of how firms answer general questions about corruption in areas unrelated to government contracting is explored by estimating two models. The first looks at whether different types of firms have different perceptions about corruption by estimating the following equation:

$$
\text { Perceptions }_{i}=\alpha+\beta \text { Aversion }_{i}+\gamma \text { Firm Characteristics }_{i}+\varepsilon_{i}
$$

Perceptions $\mathrm{s}_{\mathrm{i}}$ are how large an obstacle the manager of firm i sees corruption. Unlike the question summarized in the previous section, this is a general question about corruption (identical to question J30f). That is, it is not specifically about corruption related to government contracts. The dependent variable takes five possible values (0 to 4) corresponding to "no obstacle", "minor obstacle", "moderate obstacle", "major obstacle" and "very severe obstacle".

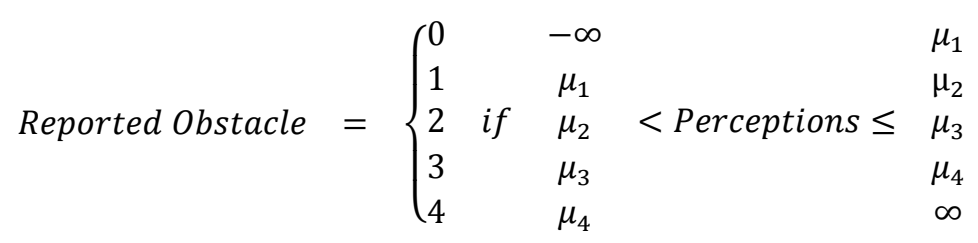

Since the dependent variable is ordered and categorical, the model is estimated as an ordered probit model.

The main variable of interest is the measure of aversion to paying bribes (aversioni). The proxies that we use are a set of dummy variables indicating what types of contracts the firms bid on. The results in the previous section suggest that firms that are averse to paying bribes avoid bidding on government contracts. We therefore divide the firms into three groups: (i) firms that bid for government contracts; (ii) firms that bid for contracts from international organizations but not from the government; and (iii) firms that have not bid for any contracts. Firms in the second, and possibly, third groups are likely to be more averse to paying bribes than firms in the first group. It is, however, difficult to know whether firms that did not bid on any contracts are averse to bidding on government contracts specifically. That is, firms that did not bid for any contracts might have had no capacity to take any additional contracts that year. As a robustness check, we drop firms that did not bid on any contracts.

Although we could divide firms that bid for government contracts into firms that only bid for government contracts and those bid for both government and international contracts, there were only 9 firms in the second category (see Table 2). We therefore separate the two groups only as a robustness check.

Firms that do not bid on government contracts worried more about corruption when bidding for contracts. As argued above, the most reasonable explanation for this is that firms that are averse to corruption choose not to bid for government contracts. If this interpretation is correct, all else equal, we would expect these firms to be less likely to pay bribes in other situations. If managers answer the indirect questions as if they are answering about their own firm, we would therefore expect firms that only bid on government contracts to be less likely to say that firms like theirs pay bribes and that corruption is a problem. 
The regression includes several control variables. The first two indicate the size and age of firms. If large firms and old firms are better connected this might affect how they deal with government officials and, therefore, their experience with corruption (Campos \& Giovannoni, 2006). The model also includes a dummy variable indicating the gender of the owner. Managers of female-owned firms might behave differently from other managers (Swamy, Knack, Lee, \& Azfar, 2001). Because corruption might affect domestic firms differently than foreign firms, the regressions include a variable indicating domestic ownership. The final variable measures time spent dealing with government regulations. This is included because the burden of regulation might affect corruption (Djankov, La Porta Lopez-de-Silanes, \& Shleifer, 2002; Safavian et al., 2001).

The second model looks at whether firms report that 'establishments like this one' make 'informal payments or gifts' to 'get things done with regard to customs, taxes, licenses, regulations, services, etc.' (i.e., J7 above). Once again, this is a general question about corruption and is not specifically about corruption when bidding for government contracts. The model is the following:

$$
\text { Firms like this one pay bribes }_{i}=\alpha+\beta \text { Aversion }_{i}+\gamma \text { Firm Characteristics }_{i}+\varepsilon_{i}
$$

The dependent variable is a dummy variable indicating that the manager says that 'firms like this one' pay bribes to get things done (Note 9). The models are estimated as a probit model containing the control variables above.

\subsection{Empirical Results}

\subsubsection{Firms That Bid on International Contracts}

Managers of firms that bid only for international contracts were more likely to say that corruption in general is a problem (i.e., J30f) than firms that bid on government contracts (see column 1 in Table 3). The coefficient indicates that firms that bid only on international contracts were about 17 percentage points more likely to say that corruption was a severe problem in other situations (see Table 4). If firms that are to averse paying bribes bid only on international contracts, it is not clear why these firms would be more likely to pay bribes in other situations. A more likely explanation for the statistically significant coefficient is therefore that firms that are averse to paying bribes are more concerned about corruption because they are less willing to pay them and therefore have problems with corrupt officials in other situations as well.

Table 3. Effect of firm characteristics on views about corruption

\begin{tabular}{|c|c|c|c|}
\hline & $\begin{array}{l}\text { Corruption is serious } \\
\text { problem }\end{array}$ & $\begin{array}{l}\text { Firms like this one pay } \\
\text { bribes } \\
\text { (missing is N/A) }\end{array}$ & $\begin{array}{l}\text { Firms like this one pay } \\
\text { bribes } \\
\text { (missing is yes) }\end{array}$ \\
\hline Number of Observations & 141 & 112 & 141 \\
\hline \multicolumn{4}{|l|}{ Bidding a } \\
\hline \multirow[t]{2}{*}{ Firm bids only on contracts with int. organizations } & $0.489 * *$ & $0.623 * *$ & $0.524 * *$ \\
\hline & $(2.10)$ & $(2.13)$ & $(2.04)$ \\
\hline \multirow[t]{2}{*}{ Firms does not bid on any contracts } & 0.260 & -0.074 & 0.013 \\
\hline & $(0.79)$ & $(-0.17)$ & $(0.04)$ \\
\hline \multicolumn{4}{|l|}{ Firm-level controls } \\
\hline \multirow[t]{2}{*}{ Number of workers $(\log )$} & -0.014 & -0.053 & -0.011 \\
\hline & $(-0.19)$ & $(-0.57)$ & $(-0.14)$ \\
\hline \multirow[t]{2}{*}{ Age of firm (in years, log) } & -0.179 & $0.542 * *$ & $0.528 * *$ \\
\hline & $(-1.02)$ & $(2.13)$ & $(2.52)$ \\
\hline \multirow[t]{2}{*}{ Firm has female owner } & 0.371 & 0.182 & 0.025 \\
\hline & $(0.99)$ & $(0.43)$ & $(0.06)$ \\
\hline \multirow[t]{2}{*}{ Firm has domestic owner } & 0.147 & $0.571^{* *}$ & $0.831 * * *$ \\
\hline & $(0.70)$ & $(2.04)$ & $(3.35)$ \\
\hline \multirow[t]{2}{*}{$\%$ of time management spends with regulators } & $0.022 * * *$ & $0.022 * * *$ & $0.018^{* * *}$ \\
\hline & $(3.76)$ & $(3.06)$ & $(3.03)$ \\
\hline \multirow[t]{2}{*}{ Constant } & & $-1.507 * *$ & $-1.433 * * *$ \\
\hline & & $(-2.56)$ & $(-2.84)$ \\
\hline Pseudo R-Squared & 0.07 & 0.16 & 0.17 \\
\hline
\end{tabular}

Source: Authors' calculations based upon data from survey.

Note: t-statistics are in parentheses. $* * *, * * *$ Statistically significant at 1,5 , and 10 percent significance levels.

${ }^{\text {a }}$ Omitted category is firms that bid on government contracts. 
Firms that do not bid on government contracts were also more likely to say that firms like theirs need to pay bribes to get things done (see column 2). If firms that do not bid for government contracts are more averse to paying bribes to win contracts, it seems unlikely that they would be more likely to pay bribes in other situations. This suggests that their responses indicate that they believe that 'firms like theirs' pay bribes rather than that they pay bribes (note 10). In summary, it is difficult to interpret the answers to these general indirect questions as if the managers are talking about the firms' own experiences.

Table 4. Estimated outcomes that firms will answer questions about corruption positively

\begin{tabular}{lccc}
\hline & $\begin{array}{c}\text { \% saying corruption is } \\
\text { severe problem }\end{array}$ & $\begin{array}{c}\text { \% saying firms like their pay } \\
\text { bribes (missing is N/A) }\end{array}$ & $\begin{array}{c}\text { \% saying firms like their pay } \\
\text { bribes (missing is yes) }\end{array}$ \\
\hline Firm bids on government contracts & $50 \%$ & $29 \%$ & $43 \%$ \\
Firm bids only on international contracts & $67 \%$ & $49 \%$ & $60 \%$ \\
Firm does not bid on any contracts & $59 \%$ & $27 \%$ & $43 \%$ \\
\hline
\end{tabular}

Source: Authors' calculations based upon data from survey.

Note: Estimated outcomes are calculated by predicting the outcome for each observation assuming that it falls into that group (i.e., replacing the appropriate dummies with the dummy for that group)

\subsubsection{Firms That Do Not Bid on Any Contracts}

The coefficients on the dummy variable indicating that the firm did not bid on either type of contract were statistically insignificant. However, there are few firms in this category (see Table 2) and, as a result, the coefficients are estimated imprecisely. In fact, we are also unable to reject the null hypothesis that the coefficients on this dummy variable are the same as the coefficients on the dummy variable indicating that the firm bids only on international contracts at conventional 10 percent significance levels. In this respect, we are unable to say much about the responses of firms that bid on neither type of contract.

Table 5. Robustness Checks

\begin{tabular}{|c|c|c|c|c|}
\hline & $\begin{array}{l}\text { Corruption is } \\
\text { serious problem }\end{array}$ & $\begin{array}{l}\text { Firms like this one } \\
\text { pay bribes (missing } \\
\text { is N/A) }\end{array}$ & $\begin{array}{l}\text { Corruption is } \\
\text { serious problem }\end{array}$ & $\begin{array}{l}\text { Firms like this one } \\
\text { pay bribes } \\
\text { (missing is N/A) }\end{array}$ \\
\hline Number of Observations & 141 & 112 & 125 & 100 \\
\hline \multicolumn{5}{|l|}{ Bidding a } \\
\hline Firm bids only on contracts with int. organizations & $\begin{array}{l}0.494 * * \\
(2.08)\end{array}$ & $\begin{array}{l}0.669 * * \\
(2.23)\end{array}$ & $\begin{array}{l}0.524 * * \\
(2.25)\end{array}$ & $\begin{array}{l}0.619 * * \\
(2.12)\end{array}$ \\
\hline Firms does not bid on any contracts & $\begin{array}{l}0.267 \\
(0.80)\end{array}$ & $\begin{array}{l}-0.015 \\
(-0.03)\end{array}$ & & \\
\hline Firms bids only on contracts with Government & $\begin{array}{l}0.045 \\
(0.11)\end{array}$ & $\begin{array}{l}0.373 \\
(0.72)\end{array}$ & & \\
\hline \multicolumn{5}{|l|}{ Firm-level controls } \\
\hline Number of workers $(\log )$ & $\begin{array}{l}-0.013 \\
(-0.17)\end{array}$ & $\begin{array}{l}-0.048 \\
(-0.51)\end{array}$ & $\begin{array}{l}-0.080 \\
(-1.05)\end{array}$ & $\begin{array}{l}-0.047 \\
(-0.48)\end{array}$ \\
\hline Age of firm (in years, log) & $\begin{array}{l}-0.179 \\
(-1.02)\end{array}$ & $\begin{array}{l}0.514 * * \\
(1.99)\end{array}$ & $\begin{array}{l}-0.257 \\
(-1.38)\end{array}$ & $\begin{array}{l}0.458^{*} \\
(1.73)\end{array}$ \\
\hline Firm has female owner & $\begin{array}{l}0.374 \\
(1.00)\end{array}$ & $\begin{array}{l}0.218 \\
(0.51)\end{array}$ & $\begin{array}{l}0.338 \\
(0.89)\end{array}$ & $\begin{array}{l}0.198 \\
(0.47)\end{array}$ \\
\hline Firm has domestic owners & $\begin{array}{l}0.146 \\
(0.70)\end{array}$ & $\begin{array}{l}0.566^{* *} \\
(2.01)\end{array}$ & $\begin{array}{l}-0.002 \\
(-0.01)\end{array}$ & $\begin{array}{l}0.571 * \\
(1.95)\end{array}$ \\
\hline$\%$ of time management spends with regulators & $\begin{array}{l}0.022 * * * * \\
(3.76)\end{array}$ & $\begin{array}{l}0.022 * * * \\
(3.07)\end{array}$ & $\begin{array}{l}0.025^{* * *} \\
(4.03)\end{array}$ & $\begin{array}{l}0.023 * * * \\
(3.03)\end{array}$ \\
\hline Constant & & $\begin{array}{l}-2.161 * * * \\
(-3.74)\end{array}$ & & $\begin{array}{l}-2.047 * * * \\
(-3.43)\end{array}$ \\
\hline Pseudo R-Squared & 0.07 & 0.17 & & \\
\hline
\end{tabular}

Source: Authors' calculations based upon data from survey.

Note: t-statistics are in parentheses. ${ }^{* *}, * * *$ Statistically significant at 1,5 , and 10 percent significance levels. Firms that bid on no contracts are excluded from regressions in last two columns

${ }^{\text {a }}$ Omitted category is firms that bid on government and international contracts. 


\subsubsection{Control Variable}

Most of the coefficients on the firm-level control variables are statistically insignificant. There were, however, some significant coefficients. Most notable, managers of domestically owned firms were more likely to say that corruption is a serious problem when bidding on government contracts and more likely to say that 'firms like theirs' paid bribes to get things done with respect to licenses, taxes, and other regulatory requirements. Managers of older firms were also more likely to say that firms like theirs paid bribes to get things done. Firm managers that reported spending more time with government officials were more likely to say that corruption was a serious problem and more likely to say that firms like theirs paid bribes.

\subsubsection{Robustness Checks}

Close to one-fifth of the surveyed contractors refused to answer the question on whether bribes are needed. It is possible that firm managers that believe that other firms like theirs pay bribes would be more likely to refuse to answer than managers that believe that firms like theirs do not pay bribes (Jensen, Li \& Rahman, 2010). As a robustness check, we re-run these regressions treating non-respondents as if they replied yes - that is the dependent variable is one if the firm manager said that firms like their paid bribes or the firm manager refused to answer. The results are similar when we do this (see column 3)

As an additional robustness check, firms that bid only on government contracts are separated from firms that bid on contracts with government and with international organizations (see Table 5). As discussed above, only a few firms bid only on government contracts meaning that the coefficient will be estimated imprecisely. The coefficient on this variable is statistically insignificant, meaning that the difference between these firms and firms that bid on both government and international contracts is not statistically significant. Including the additional dummy does not appear to affect any of the main results discussed above. Finally, the results are also similar when we omit firms that did not bid on any contracts. As discussed above, it is possible that these firms do not have any spare capacity and do not bid because of this.

\section{Conclusion}

Firms that do not bid for government contracts complain more about corruption in government contracting than firms that do bid (Clarke, 2011b). Since firms only pay bribes if they bid, it seems non-bidding firms should be less, not more, concerned about corruption in government contracting. So why do firms that do not bid complain more? One possibility is that managers that are averse to paying bribes refuse to bid for government contracts. They therefore see corruption as a serious problem for their firm because they lose contracts because of it. This shows that seeing a manager complain about corruption in government contracting does not mean the manager is paying bribes.

Firms that do not bid for government contracts were also more likely to say that corruption was a problem and that firms like theirs paid bribes in situations unrelated to bidding. If firms do not bid for government contracts because they are averse to paying bribes, it seems unlikely that they would be more willing to pay bribes at other times. This suggests managers might not answer general indirect questions only thinking about their own firm. That is, when they say corruption is a problem or that firms like theirs pay bribes, they might not be implicitly admitting to paying bribes.

If this is the case, how does it affect how we use indirect questions? One way that researchers use data on corruption is to rank countries. Even if firms answer indirect questions thinking about what other firms do, this might not affect country rankings. As long as firm managers are correct about what they think other firms are doing, it does not matter whether they answer thinking about what they do or what other firms do.

It does, however, affect other uses of indirect questions. Researchers often regress managers' responses to indirect questions on firm and manager characteristics. If firm managers are not thinking about themselves or their firm when answering these questions, results from these regressions could be misleading. That is, the other firms that managers are thinking about might be different from the managers' firm in ways that interest the researcher.

In this paper, we find managers of domestic firms are more likely to say that 'firms like theirs' pay bribes. This could be because domestic firms pay bribes more than foreign firms. If managers answer the indirect question thinking about their firm, this would be the correct way to interpret the correlation. It would also be the correct way if managers of domestic firms answer thinking about other domestic firms and managers of foreign firms answer thinking about other foreign firms.

But managers might be thinking broadly about firms in their sector or about their main competitors when they answer. Their answers might show that managers of domestic firms believe that important large foreign 
competitors in their sector pay bribes. This would be consistent with focus group discussions where managers of domestic firms complained about foreign firms using connections to win contracts.

Another example from this paper is the correlation between corruption and regulation. As noted above, managers that report spending more time with regulators were more likely to say that firms like theirs paid bribes. If they were answering with their own experiences in mind, this suggests that regulation leads to corruption or corruption leads to heavier regulation. If, on the other hand, they are talking about how they think other managers behave, it could show that they believe that spending time with regulators leads to more opportunities for corruption for their corrupt competitors. That is, the correlation might not be caused by regulation resulting in greater bribe payments, just greater opportunities to bribe.

\section{Acknowledgements}

I would like to thank Salar Jahedi, Anand Jha, Michael Wong and participants at the 2011 Western Economic Association meetings for helpful comments and discussions on earlier drafts of the paper. Responsibility for all errors, omissions, and opinions rests solely with the author

\section{References}

Azfar, O., \& Murrell, P. (2009). Identifying Reticent Respondents: Assessing the Quality of Survey Data on Corruption and Values. Economic Development and Cultural Change, 57, 387-411. http://dx.doi.org/doi:10.1086/592840.

Campos, N.F., \& Giovannoni, F. (2006). Lobbying, Corruption, and Political Influence. Public Choice, 131, 1-21. http://dx.doi.org/doi:10.1007/s11127-006-9102-4

Clarke, G. R. G. (2011a). How Petty Is Petty Corruption? Evidence From Firm Surveys in Africa. World Development, 39, 1122-1132. http://dx.doi.org/doi:10.1016/j.worlddev.2010.11.002.

Clarke, G. R. G. (2011b). The Effect of Corruption on Competition for Government Contracts. Journal of US-China Public Administration, 8, 1101-1110.

Clarke, G. R. G., and Xu, L. C. (2004). Privatization, Competition and Corruption: How Characteristics of Bribe Takers and Payers Affect Bribes To Utilities. Journal of Public Economics, 88, 2067-97. http://dx.doi.org/10.1016/j.jpubeco.2003.07.002.

Clausen, B., Kraay, A. \& Murrell, P. (2010). Does Respondent Reticence Affect the Results of Corruption Surveys? Evidence from World Bank Enterprise Survey for Nigeria. Policy Research Working Paper 5415. World Bank, Washington DC. http://go.worldbank.org/J10YIDC0A0.

Djankov, S., La Porta, R., Lopez-de-Silanes, F., \& Shleifer, A. (2002). The Regulation of Entry. Quarterly Journal of Economics, 117, 1-37. http://dx.doi.org/10.1162/003355302753399436.

IMD. (2010). IMD World Competitiveness Yearbook 2009. Lausanne, Switzerland: IMD International.

Jensen, N. M., Li, Q., \& Rahman, A. (2010). Understanding Corruption Using Cross-National Firm-Level Surveys. Journal of International Business Studies, 41, 1481-1504. http://dx.doi.org/10.1057/jibs.2010.8

Johnson, S., Kaufmann, D., McMillan, J., \& Woodruff, C. (2000). Why Do Firms Hide? Bribes and Unofficial Activity After Communism. Journal of Public Economics, 76, 495-520. http://dx.doi.org/doi:10.1016/S0047-2727(99)00094-8.

Johnson, S., McMillan, J., \& Woodruff, C. (2002). Property Rights and Finance. American Economic Review, 92, 1335-1356. http://dx.doi.org/doi:10.1257/000282802762024539

Karlan, D., \& Zinman, J. (2008). Lying About Borrowing. Journal of the European Economic Association, 6, 510-521. http://dx.doi.org/10.1162/JEEA.2008.6.2-3.510

Kaufmann, D., Kraay, A., \& Mastruzzi, M. (2009). Governance Matters VIII: Governance Indicators for 1996-2008. Policy Research Working Paper 4978. World Bank, World Bank, Washington DC. http://papers.ssrn.com/sol3/papers.cfm?abstract-id=1424591

Kuehnast, K., \& Dudwick, N. (2004). Better a Hundred Friends That a Hundred Rubles? Social Networks in Transition--The Kyrgyz Republic. World Bank: Washington DC.

Safavian, M. S., Graham, D. H., \& Gonzalez-Vega, C. (2001). Corruption and Microenterprises in Russia. World Development, 29, 1215-24. http://dx.doi.org/doi:10.1016/S0305-750X(01)00036-5.

Svensson, J. (2003). Who Must Pay Bribes and How Much? Evidence From a Cross Section of Firms. Quarterly Journal of Economics, 118, 207-230. http://dx.doi.org/doi:10.1162/00335530360535180. 
Swamy, A., Knack, S., Lee,Y., \& Azfar, O. (2001). Gender and Corruption. Journal of Development Economics, 64, 25-55. http://dx.doi.org/10.1016/S0304-3878(00)00123-1.

Tourangeau, R., \& Smith, T. W. (1996). Asking Sensitive Questions: The Impact of Data Collection Mode, Question Format, and Question Context. Public Opinion Quarterly, 60, 275-304. http://dx.doi.org/doi:10.1086/297751

Treisman, D. (2007). What Have We Learned About the Causes and Corruption From Ten Years of Cross-National Empirical Research. Annual Review of Political Science, 10, 211-244. http://dx.doi.org/doi:10.1146/annurev.polisci.10.081205.095418

Wiederman, M. W. (1997). The Truth Must Be in Here Somewhere: Examining the Gender Discrepancy in Self-Reported Lifetime Number of Sex Partners. Journal of Sex Research, 34, 375-386. http://dx.doi.org/doi:10.1080/00224499709551905

\section{Notes}

Note 1. The evidence on how successful indirect questions are in reducing underreporting is mixed. Azfar and Murrell (2009) found little evidence that reticent managers are more truthful when answering indirect, rather than direct, questions about corruption.

Note 2. The three firm-level data sources used to construct the Worldwide Governance Indicators measure corruption indirectly (Kaufmann, Kraay, \& Mastruzzi, 2009). The EBRD and World Bank's Business Environment and Enterprise Performance Survey (BEEPS) uses an approach similar to the World Bank's Enterprise Surveys asking about 'firms like yours'. The Executive Opinion Survey asks how common it is for firms (not the specific firm) to pay bribes. The World Competitiveness Survey asks whether bribery/corruption exist in the economy (IMD, 2010). Many one-off surveys also use indirect questions. See, for example, Johnson, Kaufmann, McMillan, and Woodruff (2000), Svensson (2003) and Safavian et al. (2001).

Note 3. See also, for example, Clarke (2004, p. 2077), Johnson et al. (2000, p. 504 ), Johnson et al. (2002, p. 1337-1338) and Svensson (2003, p. 212-213).

Note 4. Anonymous field interviews conducted by the author in Zambia in 2007.

Note 5. Based on estimates from this survey, international agencies and foreign militaries accounted for three quarters of public contracts in 2009.

Note 6. Only about 17 percent of firms that bid on international contracts said that bribes were needed to secure contracts compared with 38 percent of firms that bid on government contracts that said the same about these contracts.

Note 7. Clarke (2011b) shows that corruption affects the firms that bid for government contracts by discouraging firms that are averse to corruption from bidding. He also shows this might affect the quality of the firms that win government contracts.

Note 8. Discussing corruption in the Kyrgyz Republic, Kuehnast and Dudwick (2004, p. 24) note "[a]lthough bribery allows people to circumvent networks because middlemen are no longer so essential to transactions, insider connections (sviazy) remain important, since it is often through such connections that one learns who can or should be bribed, what constitutes reasonable payment, and how to time the payment."

Note 9. The question was based upon the question J7 from the World Bank's Enterprise Survey. Firms could answer either in monetary terms or as a percent of sales. Clarke (2011a) shows that firms report payments as a percent of sales report amounts between four and fifteen times higher than firms that report them in monetary terms. Because of this, it is it difficult to run regressions using the underlying continuous variable.

Note 10. If in contrast, firms that participate in bidding are less likely to say that corruption is a problem is because they are lying about the extent of corruption, then the more natural way to interpret the second result is that the same firms are also lying about other types of corruption. Again, interpreting their answers to indirect questions as describing their own actions is problematic in this case as well-they are less likely to say that corruption is a problem and that firms like theirs pay bribes not because they do not pay bribes but that they are lying about their own actions. 